second. This has made possible navigation to within 10 metres using satellites, milliarcsecond studies of celestial radio sources, studies of the Earth's rotation and precise knowledge of the Earth's gravitational field. It also affects fundamental research in areas that measure physical constants and in atomic physics and general relativity.

Time must be based on a phenomenon in nature that has a definite repeatability; this defines the frequency of the 'standard'. This frequency can be measured, but it takes an almost continuous comparison between 'standards' to determine and disseminate a unique timescale by which laboratories can synchronize their clocks to produce the unit of time, the second. Further time must also be considered in the framework of general relativity.

The measurement of time was based originally on astronomical phenomena such as the rotation of the Earth and the motion of the planets. Since 1967, however, it has been based on an atomic-frequency standard the second is defined by the use of a caesium133 atom. Our daily lives are governed by civil time, which is based on Coordinated Universal Time (UTC). This is the time at the longitude of the Greenwich meridian, from which the time zones are offset to give local civil time, which follows the rising and setting of the Sun. UTC is International Atomic Time (Temps Atomique International, or TAI) offset by an integral number of seconds in order to keep it in near-synchronization with the rotation of the Earth. As the Earth's rotation is slowing down by one hour every 1,000 years, 'leap seconds' are added to UTC (at the end of either June or December) when the discrepancy of the Earth's rotation with TAI is 0.9 seconds.

The Measurement of Time gives an excellent, detailed introduction to all aspects of time and frequency. Topics covered include principles, measurements, models, the evolution of time definitions, clock time, atomic standards, atomic time, astronomical time, ultra-precise time and frequency standards, as well as definitions and advanced time applications. All of these topics are well referenced, making this an excellent source for scientists and students in the field of time measurement as well as for historians of physics and astronomy.

Most of the book should also be accessible to a more general audience. Although there are many other books on this subject for the general public, this is perhaps the most authoritative, as it provides the precise definitions used in this field. Such knowledge could provide an interesting topic at cocktail parties when there is a lull in the conversation.

Ken Johnston is at the US Naval Observatory,

3450 Massachusetts Avenue, NW,

Washington DC 20392, USA.

\section{More on time}

Calendrical Calculations: The Millennium Edition

by Edward M. Reingold \& Nachum Dershowitz Cambridge University Press, £24.95, \$37.95 (pbk)

\title{
Clock-watching through the ages
}

\begin{abstract}
Measured time: the phases of the Moon (right), and a pocket sundial from the sixteenth or seventeenth century. From The Discovery of Time, edited by Stuart McCready (MQ Publications, E14.99).

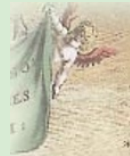

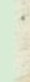

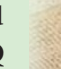

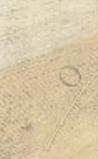

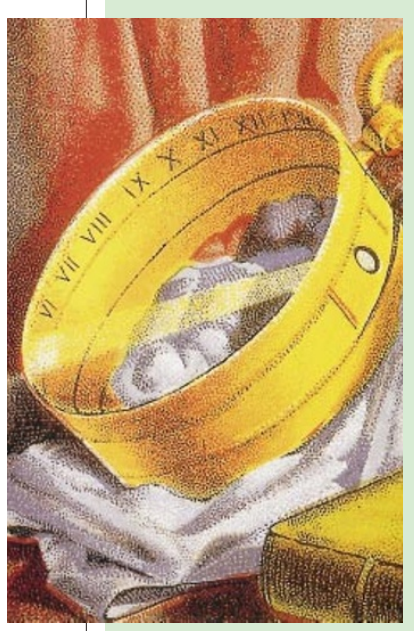

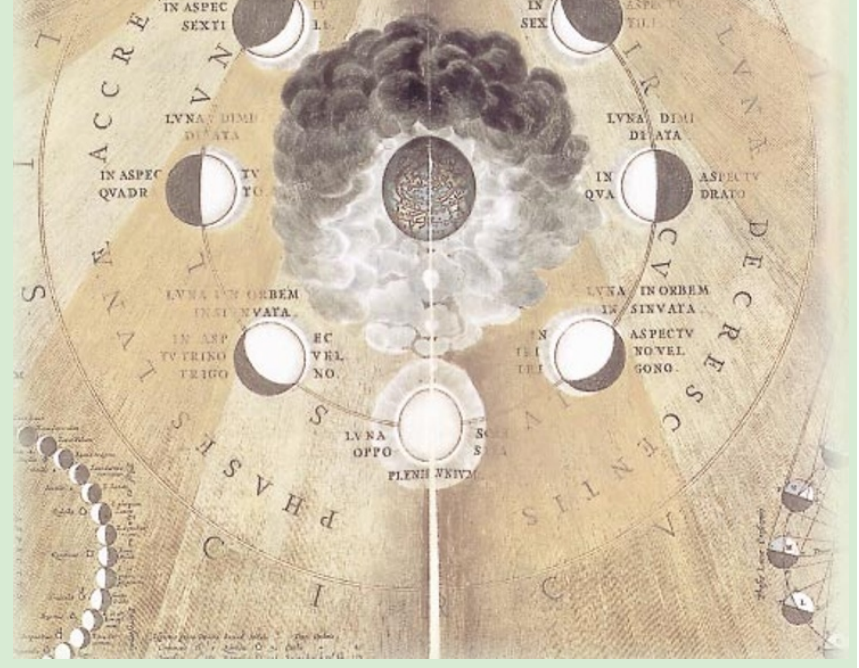

\section{When politics colours disease}

\section{Dying in the City of the Blues: \\ Sickle Cell Anemia and the \\ Politics of Race and Health \\ by Keith Wailoo \\ University of North Carolina Press: 2001. \\ 360 pp. \$34.95 (hbk), \$16.95 (pbk)}

\section{Ken Fox}

The power of black bodies and their afflictions to "tell a moral tale" about changing racial relations in US society is bound to fascinate, infuriate and inspire readers of Dying in the City of the Blues. Keith Wailoo's telling historical narrative chronicles the changing meanings - clinical, scientific, political, symbolic — of sickle-cell disease over the course of the twentieth century in America. Fundamentally, this remarkable text on the social construction of the illness speaks of how ancient, bloody, brutal and enduring the facts of racial disparity in health and care really are in the American experience.

Wailoo's meticulous scholarship excavates a deep and dizzying range of primary documentary resources. Arcane manuscript collections, nearly four dozen technical, scientific and popular journals, newspapers, fiction, blues lyrics, cartoons and sermons are mined to reveal the politics of race and health in America.

What makes this book such an achievement is the author's eye and ear for luminous detail. In one example, Wailoo uses lyrics from bluesman W. C. Handy's 1909 Memphis Blues to introduce readers to Edward 'Boss' Crump, mayor and chief architect of city politics in early-twentieth-century Memphis. Crump, "closest thing to a plantation master Memphis had", was "a Democratic Party boss who blended southern paternalism and humor with brutality toward those who disagreed with him". On election day, Crump's henchmen rounded up Handy's audiences, escorted them to the polls, and doled out gifts in exchange for votes. All the while, Crump's regime was viciously policing the boundaries of Jim Crow segregation. Wailoo thus aptly characterizes Memphis blacks as both "pawns and political forces in the urban power struggle". In another example, Wailoo brings Memphis's famous Beale Street to life. Once a potent centre of black capitalism, Beale Street was a major theatre in the holy war waged by "Negro doctors" against "sidewalk barkers" and sellers of "roots, herbs, grape leaves, rabbits' feet, wine and whiskey concoctions".

Through Wailoo's window, the politics of race and health are inextricably bound to class tensions, and central to his interpretive framework is the conception of sickle-cell disease as a 'commodity. The history of the illness may be traced along its shifting positions 
within networks of "exchange relationships, where - much like any object - the disease concept and illness experience acquire value and [can] leverage resources, money or social concessions". As spin and values of the meanings of illness are speculated, negotiated and traded upon, so too do sufferers' and scholars' fortunes rise and fall. One of the great advantages of Wailoo's approach is the way it reveals how social institutions and forces of political economy - more than the triumphant achievements of famous autonomous scholars - shape scientific inquiry and meanings of illness. Hill-Burton grants, in terms of the US Public Health Service Act passed in 1946, have stimulated hospital construction and certain kinds of medical research; philanthropic trends forge particular representations of illness; Medicare and Medicaid alter incentives to serve the sick poor; black power politics shifts cultural representations of black pain; managed care and free-market disciplines within medical markets depreciate the 'capital' — fiscal and symbolic — of academic centres. The author shows how social forces find their way "beneath the skin", into the very marrow of sickle-cell sufferers, transforming options, experiences and outcomes of care.

The text also tells how ideologies come to life. Sometimes those lives - like that of Frankenstein's monster - are absolutely wretched. For example, the disfiguring power of white racism on medico-scientific discourse is deftly documented by citing a physician, writing in 1932: "The safeguarding of the health of the Negro ... [was] anything but an easy task, for the fight is not against disease, but against physical, mental, and moral inferiority, against ignorance and superstition, against poverty and filth."

The tale is populated by many public figures of mythic proportions, but no true heroes. Even prominent black social scientists of the age were transfixed by cursed ideologies of white superiority. Wailoo cites sociologist Charles Johnson (1934): "Children die in great numbers and mothers accept their death with a dull and uninquiring fatalism." Thus, the spectre of the mentally inferior, fatalistic, apathetic and mistrustful black patient whose afflictions are consequences of her flaws - alive even to this day in emerging medical literatures on 'cultural competence' - has a lineage as long and shameful as the shadow of the plantation.

The author blows the dust off the many skeletons in the nation's closet. The ghosts of inequalities past, present and future rattle their chains and point to trouble here, behind and ahead of us. Thankfully, finally, we have, in historian Wailoo, a post-modern Indiana Jones whose rough-and-tumble vitality of practice and piercing gaze allow no place for those old bones to hide.

Ken Fox is in the Division of General Pediatrics, Boston University School of Medicine, 91 East

Concord, Boston, Massachusetts 02118, USA.

\section{Science in culture}

\section{The sum of the parts}

\section{Proof, a play by David Auburn}

Jonathan Knight

Sophie Germain, daughter of an eighteenthcentury Parisian merchant, became fascinated by mathematics at an early age, much to the chagrin of her parents, who thought such concerns were not proper for a young woman. She studied in secret, late into the night, burning a hidden supply of candles. Even after her parents came to accept her strange proclivity, she knew the outside world would not. So when she struck up a correspondence with the great mathematician Carl Gauss, she used a man's name.

She wrote to him of how she had devised a special kind of prime number and used it to make a start at proving Fermat's Last Theorem, the famous mathematical teaser that had by then been around for 130 years. Later, when Gauss found out that the author was a woman, he wrote to her that, as a member of the sex that "must encounter infinitely more difficulties than men to familiarise herself with these thorny researches", she must have extraordinary talents.

Such stories make irresistible fodder for the dramatic artist. In David Auburn's Proof, which began its national tour in the United States in November, the present-day protagonist Catherine foreshadows her own mathematical talent by telling the story of Germain. Catherine is also forced to be reclusive, not because of her sex, but to care for her ageing, schizophrenic father Robert, a mathematician who revolutionized three areas of mathematics before he "went bughouse".

Although Robert is mentally ill, he is not mad in the fiendish and clinically undefined sense of Dr Frankenstein or Dr Moreau, or even of Seth Brundle in The Fly. Robert develops schizophrenia at the age of 25 , and the disease halts his career.

Hal, Catherine's love interest and her father's former student, now a professor at the University of Chicago, discovers another brilliant mathematical proof locked in Robert's desk drawer. The question is, who wrote it, Catherine or Robert?

Auburn set out to portray mathematicians and their work as realistically as possible. By consulting real mathematicians, he avoided some of the more hackneyed stereotypes of scientists, and enriched the play with aspects of the culture of mathematics that outsiders might not know. Yet, unlike the plays of Carl Djerassi, Proof does not attempt to educate. For Auburn, mathematics is a theatrical tool, and he uses it with great skill.

Proof gives us a look inside the culture of mathematics when Hal tells Catherine it's a “young man's game". Although the general public may know that maths, like physics and the other 'hard' sciences, is a field still dominated by men, they may not know that many mathematicians worry that their best years are quickly behind them. "There's this fear that your

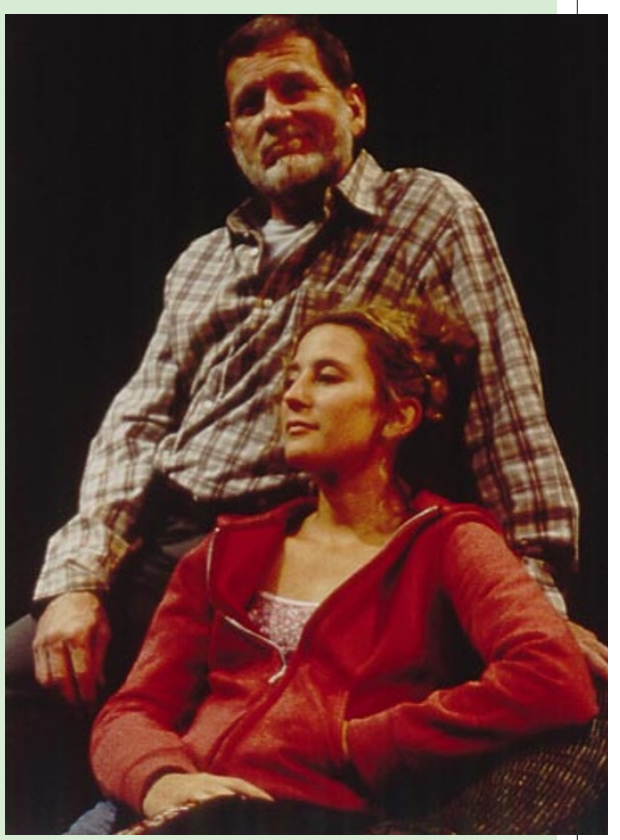

Father and daughter, mathematicians both.

creativity peaks around 23 and it's all downhill from there," Hal tells Catherine. He says many of the older guys use amphetamines to try to stay sharp, and he assumes that he will never amount to much as he is already 28 .

In a public interview with Auburn at the San Francisco theatre where the tour opened, host Bob Osserman, a mathematician at the Mathematical Sciences Research Institute in Berkeley, said he basically agreed with that portrayal. Although pill-popping is probably not rampant, as the play suggests, mathematicians do worry about losing their edge, he said. And this is unfortunate because, whether justified or not, that fear diminishes the importance of doing good, solid, non-breakthrough mathematics. "The idea that only brilliant research counts is very destructive," Osserman said.

Where Proof goes beyond the realm of reality is in asking us to believe in Catherine's amazing mathematical insight. It's true that in maths, but rarely in other scientific disciplines, great strides can be solo acts. But not even Germain achieved what Catherine says she achieves, a brilliant mathematical proof written in a few months of late nights with no more background than a genius father and a semester of college.

Nevertheless, Auburn uses mathematics as an effective dramatic tool that leaves the audience on the edge of its seat, hoping desperately that Catherine wrote the proof. The truth is not revealed until the final scene. Jonathan Knight writes for Nature from San Francisco.

Proof is playing at the Boston Wilbur Theatre until 17 February. The tour reaches the Denver Auditorium Theatre on 18 June. 